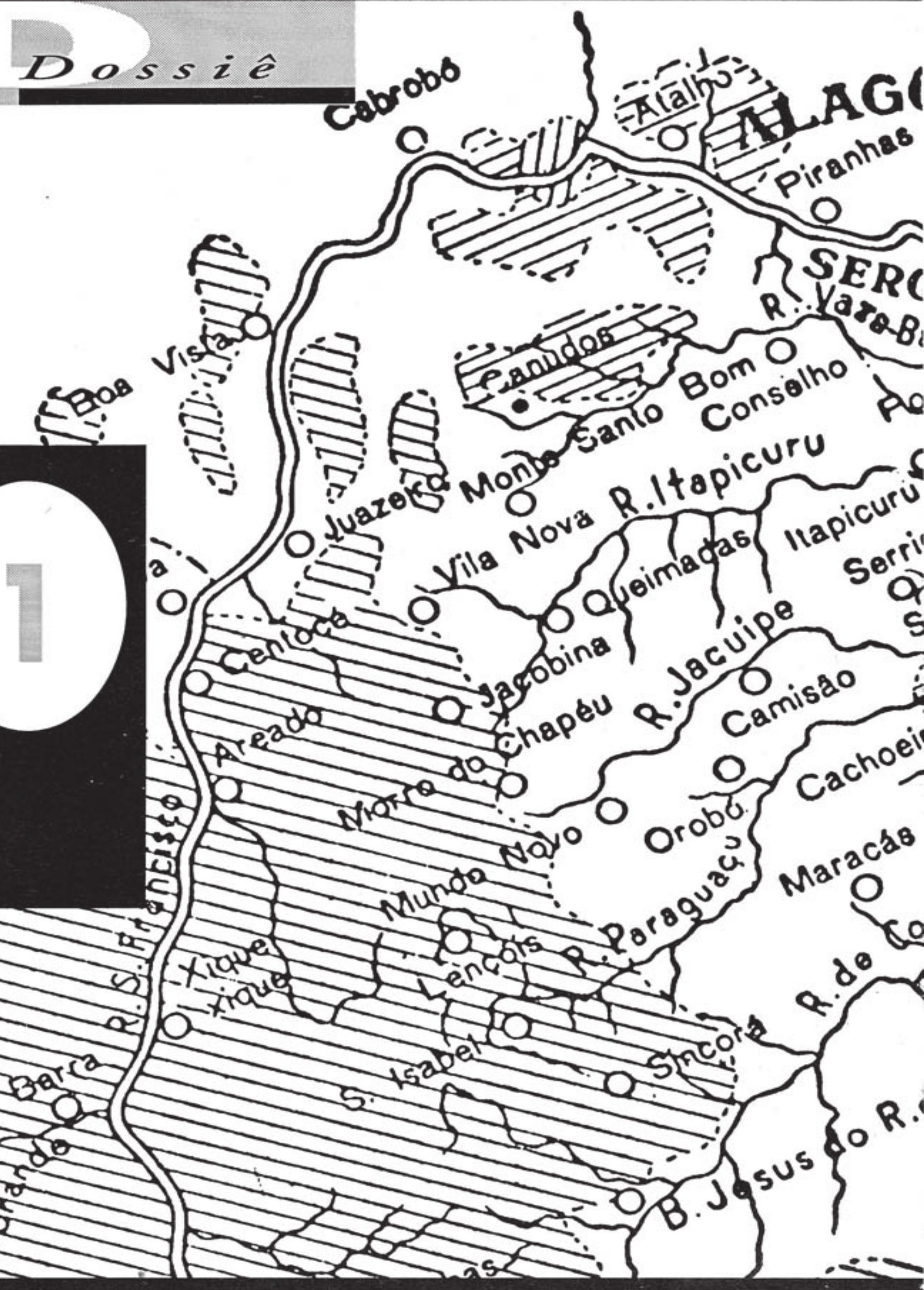




\section{Textos de José Calasans}

Apresentação de FRANCISCO COSTA

Éesta apresentação de José Calasans feita pela revista Exu, de Salvador: "folclorista, historiador, escritor. Dono de uma memória sem igual. Sua paixão: Canudos". É preciso dizer também que José Calasans é um homem da velha guarda no melhor sentido, tanto na forma de escrever, quanto na maneira de tratar o objeto de seu estudo mais profundo. O rigor é indiscutível bem comoo bom senso. Aventurou-se a mexer com o tema "Canudos" há mais de cinqüenta anos, época em que a palavra de Euclides em Os Sertōes soava como trombeta final. Sobre o tema escreveu mais de quinze livros. Orientador de várias geraçōes de estudiosos, foi uma das pessoas consultadas por Vargas Llosa ao redigir seu romance A Guerra do Fim do Mundo. Uma fonte viva, portanto, o professor Calasans, que prepara no momento uma biografia do Conselheiro, e neste dossiê Canudos apresenta um material que, mesmo já tendo sido publicado, teve circulação bas- 
tante restrita. Bom momento este para que o material circule. Consta na verdade de quatro textos. O primeiro se intitula "A Faculdade de Direitoda Bahia a Guerra de Canudos", texto do próprio José Calasans, divididoem duas partes: uma primeira, aqui, em que ele trata dos libelos escritos por ocasião dos degolamentos em Canudos pelas tropas oficiais, assinados pelos estudantes e que repelem a visão sulina da imprensa daquela época; na segunda parte, ele ergue o perfil dos lentes que trabalharam para que aquela casa de saber fosse erguida. O segundo texto, com prefácio do pesquisador, é um interessante estudo do frei JoåoEvangelista, que tentou inutilmente catequizar o Belo Monte antes das incursōes das milícias. Seguem-se uma pequena cronologia da vida do Conselheiro e vários fragmentos sobre o mesmo, coligidos pelo próprio historiador. Ou seja, apresentamos uma pequena amostra do material sobre o qual o intelectual sergipano residente na Bahia tem trabalhado, num momento em que as atençōes intelectuais estão voltadas para o centenário da revolta que, pelas características messiânicas que tomou, abalou o País.

\section{A FACULDADE DE DIREITO DA BAHIA E A GUERRA DE CANUDOS}

Em 1897, quando a guerra de Canudos ganhou proporçōes de crise nacional, a Faculdade de Direito da Bahia estava na infância. Em março do referido ano, mês fatídicoda derrotadocoronelAntonioMoreira Cesar frente aos jagunços de Antônio Conselheiro, o novo centro de estudos jurídicos do Norte do Brasil não completara seu sexto aniversário de funcionamento, fundado que fora a 15 de abril de 1891 . Seu corpo docente, constituído por alguns ilustres sabedores do direito, năo desfrutava ainda do alto conceito dos mestres da Faculdade do Recife. Seus alunos não passavam de uns calouros diante da moçada de Medicina, o primeiro colégio acadêmico da cidade do Salvador, donde saíram os doutores da Bahia, peritos na arte de curar e exímios também nas coisas de literatura. Até aquele ano, os estudantes de Medicina haviam dirigido as atividades sociais, culturais e políticas da cidade de Tomé de Souza. Dir-seia que a capital baiana, na parte referente às mencionadas atividades, dependia dos rapazes do Terreiro de Jesus e dos caixeiros da Cidade Baixa, com os quais os futuros facultativos dividiam, nem sempre de modo cordial, as tarefas de ação e reação. Pouco antes da queda da monarquia, foram eles os ativos participantes das homenagens de caráter político prestadas a Silva Jardim, por ocasião de sua passagem por Salvador, na mesma oportunidade da visita do Conde d'Eu. Estudantes que sofreram, na histórica oportunidade, as conseqüências da violência do poder policial, travestido de gente humilde, de ex-escravos, naturalmente reconhecidos à Lei Áurea, que a esposa do conde francês promulgara. Pois bem, na época da guerra de Canudos a liderança política passou das mãos dos estudantes de Medicina para os acadêmicos de Direito. Saiu do Terreiro de Jesus para a Ladeira da Praça. Os fatos aconteceram assim comose vai contar.

Oinsucessoda expediçäo Moreira Cesar contra o arraial de Canudos, que seus habitantes denominavam Belo Monte, abalou o país. O oficial vencido e morto viera precedido da fama, apontado como um militar terrivel e temido. Julgavam-no um soldado invencível, a quem o deus da guerra protegia. Omalogroda sua missãocausou verdadeiro pânico. Não era possível que sertanejos bisonhos vencessem homens de armas experimentados. Evidentemente, por detrás dopovosebastianista, outropodermaisalto se alevantava. Canudos era um núcleo restaurador, apoiado por forças monarquistas seguramente fortes. $\mathrm{O}$ que estava ocorrendo no sertāo do Vazabarris tinha ramificações em outros pontos do Brasil. Monarquistas daqui e dacolá se entendiam e se articulavam para destruição da jovem república. Os jornais do Rio de Janeiro e de São Paulo, alarmados, divulgavam notícias absurdas em tal sentido. Havia mais. Canudos era a vanguarda da restauração monárquica. Não estava, apenas, porém, na cidade do Bom Jesus Conselheiro, o perigo. Acrescentava-se que a própria Bahia, governo e povo, estava solidária com os conselheiristas, daí a força de que dispunha o Conselheiro para operar, como vinha fazendo, a ponto de vencer três contingentes do governo federal. Sentava-se a Bahia no banco dos réus. Ficava a impressão de que os batalhōes a serem enviados para os sertōes deveriam também constituir uma expedição punitiva contraa Bahia monárquica, inimiga da república de 89 . Distante dos acontecimentos, sem compreender suas verdadeiras origens, a imprensa sulista es- 
tigmatizava a gente baiana, jogando sobre seus ombros a responsabilidade do que estava sucedendo. A mocidade acadêmica do Brasil, sem as necessárias informaçōes, passou a aceitar o que se propalava indevidamente. Canudos integrava um poderoso esquema político de feição restauradora, e o povobaiano amparava oprojetode retorno da Casa de Bragança. Pensava-se assim no Brasil.

Era mister esclarecer a situação. Os jornais de Salvador, sem distinçōes partidárias, estiveram reunidos e publicaram declaração conjunta, elucidando a situaçãonuma nota pequena. Os moços acadêmicos foram além. Lançaram um manifesto, datado de 19 de março de 1897 , impresso na tipografia do Correio de Notícias, jornal que circulava nesta cidade de Salvador. O documento, assinado por estudantes de Direito, Engenharia Civil e Medicina, teria sido o primeiro pronunciamento coletivo do corpo acadêmico baiano, revestindo-se, por isso mesmo, de significação histórica. Era a defesa da Bahia feita em termos objetivos. Colocava o problema num plano diferente daquele que vinha sendo apresentado na Capital Federal. Repelindo acusações injustas, dizia o Manifesto:

"Espíritos ligeiros, para os quais uma aparênciajamaiscarecerá de provas, fundando-sena pressupostaindiferença dos baianos e na extravagante acusaçāo de cumplicidade ficta, irrisória, absurda, dos poderes do Estado na obra deletéria de um grupo de bandidos sem leis e sem ideais não hesitaram em atirar à Bahia a injúria de uma suspeita eminentemente odiosa, revoltadoramente injusta!... Por isso nós, estudantes das escolas superiores desta cidade, resolvemos explicar perante os republicanos dos outros estados as razões da nossa atitude, as quais constituem ao mesmo tempo a justificação completíssima do procedimento da Bahia inteira".

Bem entendido o problema em seu aspecto político, o Manifesto dos Estudantes das Escolas Superiores da Bahia aos seus Colegas e aos Republicanos dos Outros Estados não situou em seus devidos termos os componentes sociais do fenômeno. $\mathrm{Ou}$ melhor, encarou a questāo como o vinham fazendo o governo e a imprensa. O Santo Conselheiro orientava uma malta de malfeitores, exclusivamente levados pelo fana- tismo, sem nenhum ideal. Afirmavam os jovens baianos:

"O fanatismo rebelado em Canudos é uma nódoa, uma vergonha que cumpre extinguir de pronto e por completo; mas em todos os planos que tem atravessado, desde a resistência oposta aos primeiros contingentes policiais contra ele enviados até o último encontro em que, já quase vencido, viu-se de repente salvo e, ainda mais, vitorioso, em conseqüência da morte de um valente, nem uma só vez chegou a ensombrar, com a ameaça sequer de um perigo, instituições republicanas".

Convencidos de que a república não estava ameaçada, os signatários do Manifesto justificavam perante colegas de outros estados, que haviam revelado sua preocupação pelo destino das instituiçôes vigentes, a tranqüilidade da gente baiana em face dos acontecimentos sertanejos. Próximos do local da insurreiçäo, conheciam sua verdadeira natureza. Não havia motivopara a inquietação do Brasil mal informado. $\mathrm{O}$ pronunciamento teve repercussão, sobretudo depois que Rui Barbosa, falando na sua cidade natal, quando a confusão era grande, sentenciou:

"Na sábia inexperiência destes mancebos vi rutilar o gênio dos antepassados, como se a longa claridade do tempo, coada através de gerações, se refletisse, concentrada por eles, naobjetiva de uma lente diamantina. Jovens, fostes vós os estadistas enquanto os homens de Estado se fizeram crianças".

Noventa e quatro assinaturas apostas ao Manifesto.Predominavamos estudantesde Direito,emnúmerode 64, enquanto 18 eram de Medicina e 12 de Engenharia Civil. Alguns nomes se tornaram conhecidos no decorrer da vida profissional ou política. $\mathrm{O}$ jurista e político Joāo Mangabeira, Vital Soares (que foi governador da Bahia e vicepresidente eleito do Brasil), Bernardino Madureira de Pinho, Metódio Coelho, Almachio Diniz, no rol dos bacharéis; Francisco de Souza no grupo dos engenheiros; Alvim Martins Horcades, autor de um livro sobre a campanha de Canudos, entre os alunos de Medicina.

A iniciativa do valioso documento partiu da Faculdade de Direito. Exatamente da 
turma que se diplomou em $1898 \mathrm{e}$ da qual foi orador Vital Henrique Batista Soares, que proclamou:

"quando, naquela tristíssima fase de luto e sobressaltos, o medo invadia os espíritos e o pavor confrangia as almas dos maisfortes; doseiodesta Academia soou o toque de rebate-não à convocação da mocidade para as fileiras combatentes contra os fantasmas dos delírios republicanos - mas o chamamento dessas reservas, nãomanchadas ainda nas lutas da politicagem para virem dizer, da eminência de suas convicçōes puras a verdade dos fatos, que não eram os romances inventados pelos cérebros escaldados...”.

Anos depois, em 1927, escrevendo ao professor Bernardino José de Souza, secretário do Instituto Geográfico e Histórico da Bahia, Vital Soares prestou novos esclarecimentos a respeito da ação desenvolvida pelos colegas, dizendo:

"a turma de bacharéis de 1898, justamente a que tendo antes promovido o Manifesto ao País, reivindicador da verdade sobre a tragédia de Canudos, se pôs à frente da reação de piedade pelas vítimas da Civilização, dessa iníqua civilização que as deixara caírem presas do fanatismo para vir depois puni-las do crime da sua ignorância".

Terminada a sangrenta luta dos sertões, voltariam os acadêmicos baianos ao proscênio, numa nova e corajosa declaração, que tomou o título de $A$ Nação. A Faculdade de Direito da Bahia. O documento, datado de 3 de novembro de 1897 ,é um protesto. Nele se condenam os degolamentos de Canudos, praticados nos derradeiros dias da campanha fratricida. Já ago$\mathrm{ra}$, possivelmente porque seus autores quisessem marcarbem a posiçāo do Direitoem face dos crimes cometidos, omanifestotraz, apenas, as assinaturas de estudantes $\mathrm{da} \mathrm{Fa-}$ culdade de Direito da Bahia. Os signatários de novembro são em menor número que os subscritores de março. No Protesto figuram apenas 41 nomes, enquanto no Manifesto eram 64. Desconhecemos os motivos da diminuição das assinaturas. Procuramos sabê-lo, sem que obtivéssemos qualquer informação esclarecedora. Apuramos, em termos numéricos, que 41 acadêmicos apa- recem nos dois documentos, 35 no primeiroe 12 nosegundo. Assinaram os dois, entre outros, Metódio Coelho, VitalSoares, Pedro Licínio, Bernardino Madureira de Pinho, Abílio de Carvalho, Celso Spínola, Ariston Martineli, Agenor Martineli, Raul Passos; o primeiro, João Cavalcanti Mangabeira, Ernesto Sá Júnior, Gustavo Kelsch, Almachio Diniz Gonçalves e, finalmente, apenas o último, Afonso Glicério da Cunha Maciel Filho, Helvécio Ribeiro de Araújo, Augusto Pedreira Maia, Eduardo Teixeira, para citar alguns nomes. Não teria sido difícil as assinaturas para o Manifesto de março, porém, seguramente, se tornou problemático obtê-las para o Protesto de novembro. $O$ primeiro procurava esclarecer uma situação. Era a defesa da Bahia. O segundo verberava contra atrocidades praticadas nos sertōes baianos. Era um libelo acusatório. Denunciava um crime. Apontava o vencedor dito civilizado como mais bárbaro do que o vencido considerado fanático. A responsabilidade dos crimes cometidos era atribuída ao Exército Nacional, que voltava vencedor de uma campanha ingrata. Aluta fora realmente terrível, numa seqüência de fatos reveladores da incompreensão nacional, da desorganização em que vivíamos. Alguns militares, na fase final da luta, excederam-se desumanamente. A prática da gravata vermelha, isto é, o degolamento, foi realizada sem a menor dúvida. Os depoimentos neste sentido são indiscutíveis. Euclides da Cunha e Alvim Martins Horcades deixaram informações seguras a tal respeito. Seus principais responsáveis teriam sido soldados do sul, que haviam participado de atrocidades iguais nas guerras do federalismo. Traziam dos prélios dos pampasodesamor pela vida do adversário. Os atos vergonhosos de alguns enodoaram a expedição "Arthur Oscar". Não admitiram, os acadêmicos da Faculdade de Direito da Bahia, que a tropa vitoriosa chegasse a Salvador somente para receber entusiásticas manifestaçöesde apreço do governo e do povo. Era necessário que se fizesse ouvir uma voz de protesto, que debalde os moços esperaram surgisse para "vingar o direito, a lei e o futuro da República conculcados e comprometidos no cruel massacre que, como toda a população desta capital já sabe, foi exercido sobre prisioneiros indefesos e manietados em Canudos e até em Queimadas". Orepresentante da lei, enfatizava o Protesto, não podia se colocar acima da lei. Não servia à 
república, que se queria sustentar e defender, com as revoltantes degolaçöes de $\mathrm{Ca}$ nudos. Concluía omanifesto, de modoenérgico:

\footnotetext{
"Aquelas mortes pela jugulação foram, pois, uma desumanidade sobreposta à flagrante violação da justiça. Já não há Caracalas; e se houvesse, os alunossignatários, quebrando embora a estrondosa harmonia dos hinos triunfais e o concerto atroador das deificaçōes miraculosas, cumpririam apesar deleso seu dever, proclamando as palavras de justiça e de verdade que aí ficam e que, porventura, concorrerão para impedirno futuro a triste renovação de semelhantes atrocidades".
}

O manifesto foi distribuído em avulsos pela cidade, e um dos signatários do pronunciamento, o acadêmico Abílio de Carvalho, intérprete dos seus colegas nas homenagens prestadas aos estudantes de $\mathrm{Me}$ dicina, que haviam abnegadamente prestado serviços nos hospitais de sangue de $\mathrm{Ca}$ nudos, numa solene cerimônia realizada no salãonobre da Faculdade de Medicina, com a presença do mundo oficial, bateu na mesma tecla do manifesto, asseverando:

"Ser herói não é simplesmente vencer, mas vencer com justiça, respeitando o direito. Nãoforam heróisos degoladores de Belém, mas foi Cristo sobre a cruz; não foram heróis os que acenderam as fogueiras da inquisição mas os que morreram pela verdade; heróis são todos os que têm sofrido pela ciência, pela justiça, pela humanidade; são finalmente os vencedores que não deslustram o triunfo com o extermínio atroz dos submetidos".

Os aplausos que tais palavras receberam do auditório, segundo a tradição por nós recolhida, serviriam para comprovar o apoio público à nova manifestação da estudantada da Ladeira da Praça. Contounos um velho advogado baiano, Alberto de Oliveira Teixeira, ter visto um estudante de Medicina, Antônio do Prado Valadares, depois mestre consagrado em nosso estado, entregar pessoalmente à alta patente do Exército, durante ato público, um exemplar do manifesto, num gesto de evidente tom corajoso. O Protesto tornou-se arma do combate, que nós denominaríamos hoje luta

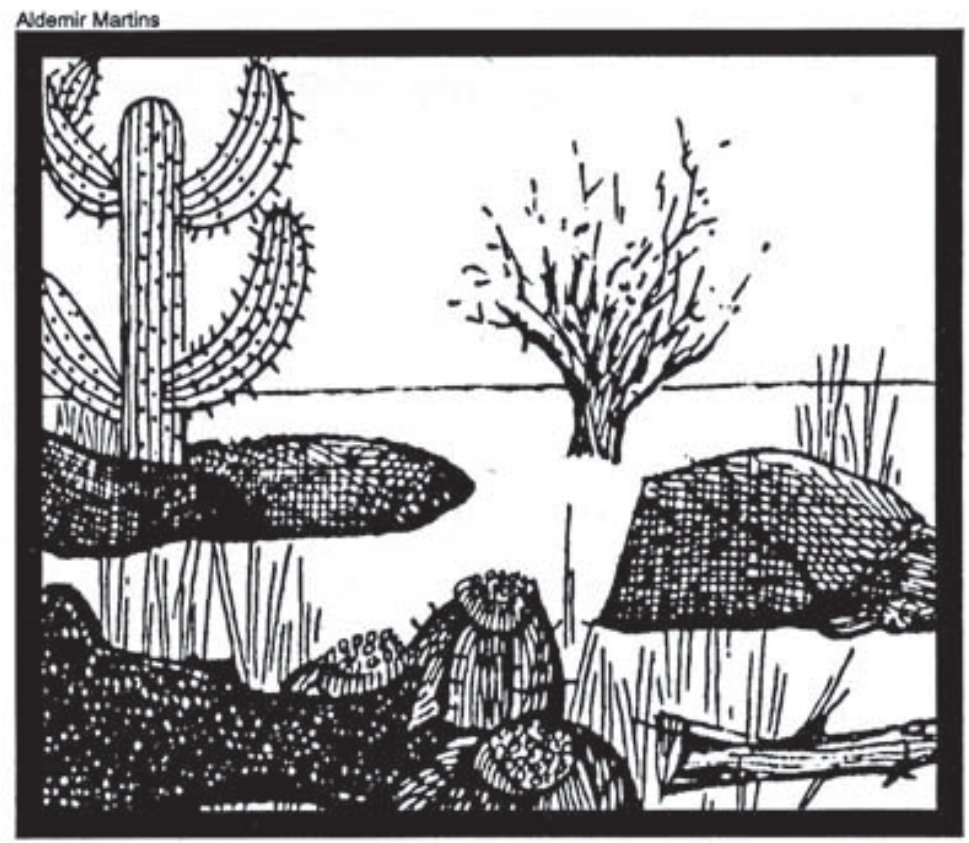

pelos direitos humanos, que tantos entraves encontra. Também nos idos de 97 , conforme registrou Vital Soares, a demonstração acadêmica correu perigo. Disse ele:

"Devem lembrar-se os contemporâneos daquela jornada histórica de que tais manifestaçōes não se operaram sem ris$\cos$. Ao menos por isso valham mais que outros que surgiram depois, quando já não havia perigos a afrontar".

Na história deste manifesto consta sempre que seu autor foi acadêmicode Direito Metódio Coelho (1872-1936), pernambucano, natural de Petrolina, desde cedo vivendo na Bahia, tendotido destacada atuaçāo no jornalismo, fundador e diretor do Jornal Moderno. Aqui também exerceu a advocacia, ocupou cargos públicos, fez política, dedicado amigo de Rui Barbosa, que nele depositava inteira confiança. Duas pessoas coetâneas dos acontecimentos, que figuram no rol dos assinantes do famoso Manifesto, deixaram escrito haver sido Metódio Coelho o redator do documento. Uma delas foi o advogado Celso Spínola, que consignou, na Revista dos Tribunais, vol. $47, \mathrm{n}^{2} 3$ (maio-julho/1953):

"Reproduziremos um documento, que se tornou histórico, o vibrante Manifesto dos intrépidos estudantes da nossa querida Faculdade de Direito da Bahia, dirigida à Naçāo, em 1897, condenando o degolamento dos prisioneiros de $\mathrm{Ca}$ - 
nudos pelas forças legais, cujo manifesto foi redigido pelo então já notável acadêmico Metódio Coelho, de saudosa memória".

A outra declaração peremptória é de Vital Soares, na citada carta a Bernardino de Souza, arquivada no Instituto Geográfico e Histórico da Bahia. Na oportunidade, Vital Soares entregou à guarda do sodalício baiano os originais do manifesto, com todas as assinaturas. O documento estava em seu poder desde 3 de novembro de 1897 , quando foi assinado, por sinal na data natalícia do futuro governador da Bahia. Por isso mesmo, Metódio Coelho, amigo fraternal, deu ao aniversariante aquele presente, por ele guardado até 10 de dezembro de 1927, quando fez sua doação ao Instituto Histórico. Lê-se na epístola de Vital Soares:

"Conservei-o em meu poder desde sua data-3 de novembro de 1897 , dádiva de Metódio Coelho, seu autor, que entregando-me quis festejar assim o meu aniversário, coincidente no mesmo dia".

Nâo havia dúvida a respeito da autoria do já tantas vezes referido documento. Metódio Coelho, juntamente com Abílio de Carvalho e Vital Soares, formava um grupo atuante na área estudantil em 1897. Ele, sobretudo, movimentava os colegas, tomando iniciativas. Foi o primeiro signatário dos pronunciamentos de março e de novembro de 1897 . Seria, portanto, o estudante que redigiu os dois documentos, $c 0-$ nhecida que era sua capacidade de escrever. Recentemente, porém, sem discutir o assunto, Francisco Mangabeira, na biografia do jurista e político João Mangabeira, declara haver sido seu ilustre pai o autor do Manifesto. Está escrito na obra de Francisco Mangabeira:

"Mas ao se verificar o espetáculo do degolamento de bravos, mas ignorantes sertanejos, Joảo Mangabeira, na Faculdade, redigiu com seu colega de turma Bernardino Madureira de Pinho o vibrante manifesto dos acadêmicos baianos, estigmatizando aquele barbarismo indigno de um povo civilizado e afronta às tradiçōes da Bahia".

Desconhecemos as fontes usadas pelo professor Francisco Mangabeira. Talvez apenas a tradição oral, conversas de família, de amigos do grande brasileiro. Porque, em verdade, João Mangabeira, por motivos que não apuramos, sequer assinou o manifesto de novembro. Sua assinatura aparece, apenas, nopronunciamentode março, onde está também o nome de um dos seus irmãos, o estudante de Farmácia Carlos CavalcantiMangabeira. Nosdoisdocumentos, sim, consta o nome de Bernardino Madureira de Pinho, a quem Francisco Mangabeira atribui a co-autoria de redação, diplomando-se no ano da guerra de Canudos, como João Mangabeira.Pelovisto, continuamos afirmando, com fortes fundamentos, que Metódio Coelho foi, realmente, o autor do À Nação. Faculdade de Direito da Bahia.

$\mathrm{Na}$ publicação comemorativa do $90^{\circ}$ aniversário da nossa Faculdade, organizada pelo eminente mestre Orlando Gomes, julguei oportuno evocar este momento de sua história, quando os acadêmicos da época assumiram a responsabilidade de levar ao país esclarecimentos e protestos da maior significação. Dir-se-á que estes manifestos e o discurso de Abílio Carvalho constituem a apresentação da Faculdade à Bahia e ao Brasil, na defesa da verdade, da justiça, dos direitos humanos. Valha, agora, a advertência de Vital Soares nos anos 20 , lembrando o feito de 97 :

"Nunca o esqueça a nossa Faculdade, só por isto gloriosa, quando, por outros títulos, nâo o devesse ser".

\section{FONTES}

SOARES, Vital. Discursos e Conferências. Rio de Janeiro, Livraria Editora Leite Ribeiro, 1929.

BARBOSA, Rui. "Discurso", in A Bahia de 25 de maio de 1897.

"Documento Memorável", in Diário Oficial (Bahia) de 23 de dezembro de 1927.

Manifesto dos Estudantes das Escolas Superiores da Bahia aos seus Colegas e aos Republicanos dos

Outros Estados. Bahia, Tipografia do Correio de Notícias, 1897.

"Campanha de Canudos", in Revista dos Tribunais, vol. 47, n²3, Bahia, maio-julho/1953.

Guia da Faculdade de Direito, Bahia, 1955.

MANGABEIRA, Francisco. João Mangabeira - República e Socialismo no Brasil. Rio de Janeiro, Paz e

Terra, 1979. 


\section{O RELATÓRIO DE FREI JOĀO EVANGELISTA \\ Apresentação de José Calasans}

A fixação do Conselheiro em Canudos, no ano de 1893, denominando Belo Monte pelo seu ocupante, passou a constituir preocupação dos jornais baianos. Os correspondentesinterio-ranosfreqüentemente enviavam suas notícias, muitas vezes transformadas em apelos ao governo para adotar providências contra os abusos cometidos pelos jagunços nas redondezas do arraial e pelo perigo que existia no crescimentodaquele lugarejo, onde não eram respeitadas as autoridades republicanas e se combatia o regime vigente. Na quase totalidade das correspondências, pedia-se uma medida enérgica e urgente para a extinção daquele "pernicioso" foco monarquista. Rarissimamente se apresentava alguém na tentativa de minimizar a gravidade da situação, sugerindo medidas apaziguadoras para reduzir o poderio do Conselheiro, e tranqüilamente convencer seus adeptos da necessidade de retorno às terras de origem, que estavam em completo abandono, com prejuízos incalculáveis para a boa marcha do trabalho e da produção. Pelas colunas dos três principais diários de Salvador, o jornal de Notícias, o Diário da Bahia e o Diário de Notícias, entre 1893 e 1895, liase, com insisténcia, noticiário sobre o Conselheiro e seu povoado. De Monte Santo, mais do que de qualquer outro ponto do estado, em razão de ser o quartel-general conselheirista localizado em terras do município, o correspondente local, de quinze em quinze dias, nas cartas regularmente remetidas, chamava a atenção do leitor para as ocorrências de Belo Monte. Teria sido, certamente, $o$ anônimo rabiscador montesantense o homem que mais comentou a situaçāo, lembrando, de modo invariável, a urgente necessidade de se encontrar um meio de conter a gente do "Bom Jesus"(1).

Desde os primeirostemposdocasoConselheiro muitas pessoas acreditaram que competia à Igreja Católica, fazendo valer seu prestígio, interferir visando dissolver o ajuntamento pela palavra de um missionário habilidoso. $\mathrm{O}$ terço em vez do fuzil era a soluçăo preconizada. $\mathrm{O}$ governador do estado, Rodrigues Lima, em 1895, resolveu solicitar a colaboração do Arcebispado, embora estivesse muito em moda proclamar o cumprimento do ato do Governo Provisório separando a Igreja do Estado. $\mathrm{O}$ arcebispo da Bahia, D. Jerônimo Tomé, em vésperas de viajar para Roma, aquiesceu ao pedido e encarregou frei João Evangelista do Monte Marciano (1843-1921), capuchinho italiano, de dirigir a delicada missão. O frade se fez acompanhar de outro companheiro de ordem, frei Caetano de S. Leo, que chegara à Bahia um ano antes da tarefa. Ao missionário juntou-se o vigário do Cumbe, padre Vicente Sabino dos Santos, que pastorava o rebanho de Canudos, com alguma frequência, ali tendo casa para se alojar. A iniciativa pacificadora veio a ser frustrada. $O$ frade italiano nāo possuía as qualidades essenciais para levar a bom termo ação religiosa tão importante. Após uns poucos dias de permanência em Canudos, a trindade missioneira teve de abandonar o local, agravando assim o relacionamento dos canudenses com o poder público. Se, porém, a finalidade do missionário redundou em malogro, o Relatório elaborado, impresso e divulgado longamente, passou a constituir elemento essencial à história do núcleo dito "monarquista" do interior baiano. Disse-nos, certa feita, frei Inocêncio, capuchinho, que conhecera pessoalmente frei JoãoEvangelista, com quem morara no Convento da Piedade, Bahia, haver sido o conhecido Relatório redigido pelo monsenhor Basílio Pereira (18501930), personalidade de relevo no clero baiano, escritor e orador conceituado, irmão dos ilustres doutores Manuel Vitorino Pereirae Antônio Pacífico Pereira. Osacerdote era muitoligadoaos frades capuchinhos do Convento da Piedade. Realmente, tudo nos leva a crer haver sido de sua autoria o valioso documento, escrito em boa linguagem. O chefe da missão não se distinguia pela clara redação. Falava de maneira desabrida, misturando a língua materna com o idioma da terra de adoção. Suas pregações, segundo a tradição corrente, eram repletas de ameaças anunciadoras de tremendos castigos celestiais. Por isso mesmo, inábil no encaminhamento de problema tãosignificativo e sensível como o episódio do Belo Monte. Malograda a louvável iniciativa pacificadora, restou, como dissemos, o Relatório informativo, embora, evidentemente, parcial, apaixonado mesmo em alguns pontos. Deu-nos ele, contudo, pela primeira vez, uma notícia geral da comunidade messiânica, aspecto de sua vida cotidiana, pormenores dos seus costumes, novas de alguns cabecilhas da grei, o péssimo estado sanitário do povoado, as atitudes

\footnotetext{
1 José Calasans, "O Dlário de Noticias a a Campanha de Canudos", in Universitas $n^{*}$ 18, Bahia, set.dez/1977.

2 Frei Gregorio de S. Mariano. "Os Capuchinhos na Bahia". in Anais do Congresso de História da Bahia. 1. Salvador, 1950, pp. 573.83. Transcreve o Rolatorio publicado creve o Rolatorio, publicado em 1895 pelo governo da
Bahia.
} 
agressivas de exaltados seguidores do líder Antônio Conselheiro. Julgando haver encontrado um agrupamento rebelado, desrespeitador da lei, cerceador das liberdadespúblicas, indicava para resolver aquele flagrante atentado as necessárias providências do poder civil para o restabelecimento da lei e do culto católico. Em resumo, pedia a intervenção do governo estadual (2). A missão mal-orientada contra a qual se manifestou Carlos de Laet.

ORelatório sobre Antônio Conselheiro e seu Séquito no Arraial dos Canudos, (Bahia, Tipografia do Correio de Notícias, 1895), com oito páginas, encerra, por assim dizer, o primeiro período da historiografia relativa à guerra de Canudos. Ele tem servido de base para o conhecimento da gente canudense e do seu poderoso chefe antes que chegasse a renhida e destruidora luta dos anos 96 e 97 . Sendo, como realmente é, um relato oficial, o trabalho de frei João, pela circunstância de sua passagem, embora rápida, por Canudos, ganhou proporções de documento básico. O professor José Augusto Cabral Barreto Bastos, em sua dissertação de mestrado, A Ideologia dos Discursos sobre Canudos(Salvador, 1979, ed. mimeografada), estudou o Relatório.

Há tambémum trabalhodogeneral João Pereira de Oliveira, Missäo de Paz a Canudos (Rio de Janeiro, Imprensa do Exército, 1987).

Relatorio apresentado, em 1895, pelo Reverendo Frei João Evangelista de Monte Marciano, ao Arcebispado da Bahia,sobre Antonio "Conselheiro" eseu sequito no arraial dos Canudos (*)

Exm.ervm.sr.-Nãoignorav.ex.rvma. que oexm.ervm.sr.arcebispo, nas vesperas da sua viagem para a visita ad limina apostolorum, confiou-me a ardua missão de ir aopovoadodos Canudos, freguezia do Cumbe, onde se estabeleceu o individuo conhecido vulgarmente por Antonio Conselheiro, afim de procurar pela pregaçăo da verdade evangelica, e, appellando para os sentimentos da fé catholica que esse individuo diz professar, chamal-o e a seus infelizes asseclas aos deveres de catholicos e de cidadãos, que de todo esqueceram e violam habitualmente com a praticas as mais extravagantese condemnaveis, offendendo a religiâo e perturbando a ordem publica. Comprehendendo bem as graves difficuldades da tarefa, acceitei-a, como filho da obediencia e confiado só na misericordia e no poder infinito d'Aquelle que, para fazer o bem, serve-se dos mais fracos e humildes instrumentos, e não cessa de querer que os mais inveterados peccadores se convertam e se salvem.

Munido, entẩo, de faculdades e poderes especiaes, segui acompanhado de um outro religioso, frei Caetano de S. Leo; e, hoje, desempenhada, como nos foi possivel a incumbencia recebida, venho relatar minuciosamente av. ex. rvma. oque observamos e qual o resultado dos nossos esforços, em parte frustrados, para que tenhav. ex. rvma. sciencia de tudo, e providencie como for conveniente, na qualidade de governador do arcebispado.

Principiarei por dizer que, partindo a 26 de abril, só a 13 de maio conseguimos entrar no povoado dos Canudos, apezar do nosso empenho em transportar-nos o mais depressa possivel. As difficuldades em obter conducções e encontrar agasalho nas estradas, e guias conhecedores do caminho, retardaram a viagem, forçando-nos a uma demora de muitos dias no Cumbe, que ainda fica a 18 leguas dos Canudos.

Ainda tāo distantes, já deparavamos os prenuncios da insubordinaçāo e anarchia de que iamos ser testemunhas, e que se fazem sentir por muitas leguas em derredor do referido povoado.

Tres leguas antes de chegar ao Cumbe avistamos um numeroso grupo de homens, mulheres e meninos quasi nus, agglomerados em torno de fogueiras, e, acercandonos delles, os saudamos, perguntando-lhes eu si era aquella a estrada que conduzia ao Cumbe.

Seu primeiromovimento foi lançar mão de espingardas e facōes que tinham de lado, e juntarem-se todos em attitude aggressiva. Pensamos accalmal-os, disse-lhes que eramos dois missionarios que se tinham perdido na estrada e queriam saber se era longe a freguezia. Responderam: "não sabemos; perguntem alli", e apontaram uma casa visinha.

Era uma guarda avançada do Antonio Conselheiro, essa gente que haviamos encontrado.

Annunciada no Cumbe, a missa conventual dodomingo 5 de maio, a missão que iamos dar nos Canudos não foi para os habitantes desse povoado uma surpreza a nossa chegada no dia 13 ás 10 horas da manhã.

Afazenda Canudos dista duas leguas do 
Riachodas Pedras, no lado opposto á serra geral. Á uma legua de distancia o terreno é inculto, porémoptimopara a creaçãomiuda, principalmente nas cheias do rio Vasa-Barris.

Um kilometro adiante descobre-se uma vasta planicie muito fertil, regada pelo rio, na baixa de um monte, de cuja eminencia já se avistam a casa antiga da fazenda Canudos, a capella edificada por Antonio ConseIheiro, $\mathrm{e}$ as miserrimas habitaçōes dos seus fanatisados discipulos.

Passado o rio, logo se encontram essas casinholas toscas, construidas de barro e cobertas de palha, de porta, sem janella, e não arruadas. $\mathrm{O}$ interior é immundo, e os moradores, que, quasi nus, sahiam fóra a olhar-nos, attestavam no aspecto esqualido e quasi cadaverico as privações de toda a especie, que curtiam. Vimos depois a praça, de extensão regular, ladeada de cerca de doze casas de telha, e nas extremidades, em frente uma á outra, a capella e a casa de residencia deAntonio Conselheiro. Áporta da capella e em varios pontos da praça apinhavam-se perto de mil homens armados de bacamarte, garrucha, facäo, etc., dando aos Canudos a semelhança de uma praça d'armas ou melhor d'um acampamento de beduinos.

Usam elles camisa, calça e blusa de azulāo, gorro azul á cabeça, alpercatas nos pés. Oarinquietoe oolhar ao mesmotempo indagador, e sinistro denunciavam consciencias perturbadas e intençōes hostis.

Alojamo-nos numa casa de propriedade do revm. vigario do Cumbe, que nos acompanhava e alli não havia voltado desde que á cerca de um anno soffrera grande desacato. Logo, após a nossa chegada, no decurso apenas de duas horas pude ver o seguinte, que dá a medida do abandono e desgraça em que vive aquella gente: passaram a enterrar oito cadaveres, conduzidos por homens armados, sem o minimo signal religioso. Ouvitambém que issoé um espectaculo de todos os dias e que a mortalidade nunca é inferior, devido ás molestias contrahidas pela extrema falta de asseio e penuria de meios de vida, que dá lugar até a morrerem á fome.

Refeitos um pouco da nossa penosa viagem, dirigimo-nos para a capella onde se achava entāo Antonio Conselheiro, assistindo aos trabalhos de construcçāo; mal nos perceberam, os magotes de homens armadoscerraram fileiras juntoáporta da capella, e ao passarmos, disseram todos: "Louvado seja Nosso Senhor Jesus Christo", saudação frequente e commum, que só recusam em rompimento de hostilidades. Entrando, achamo-nos em presença de Antonio Conselheiro, que saudou-nos do mesmo modo.

Vestia tunica de azulāo, tinha a cabeça descoberta e empunhava um bordão: os cabellos crescidos, sem nenhum trato, a cahirem sobre os hombros: as hirsutas barbas grisalhas, mais para brancas; os olhos fundos, raras vezes levantados para fitar alguem, orosto comprido, e de uma pallidez quasi cadaverica; o porte grave e ar penitente, davam-lhe ao todo uma apparencia que não pouco teria contribuido para enganar e attrahír o povo simples e ignorante dos nossos sertōes.

As primeiras palavras que trocamos versaram sobre as obras que se construiam, e elle convidou-nos a examinal-as, guiando-nos a todas as divisões do edificio.

Chegados ao côro, aproveitei a occasião de estarmos quasi sós, e disse-lhe que o fim a que eu ia era todo de paz, e que assim muito estranhava só enxergar alli homens armados, e não podia deixar de condemnar que se reunissem num logar tão pobre tantas familias, entregues á ociosidade e num abandono e miseria taes, que diariamente se davam de 8 a 9 obitos.

Por isso, de ordem e em nome do sr. arcebispo, ia abriruma santa missão, e aconselhar o povo a dispersar-se e a voltar aos lares e ao trabalho, no interesse de cada um e para o bem geral.

Emquanto dizia isto, a capella e o côro enchiam-se de gente, e ainda nāo acabava eu de falar, já elles a uma voz clamavam: "Nós queremos acompanhar o nosso Conselheiro". Este os fez calar, e voltando-se para mim, disse: "É para minha defeza que tenho commigo estes homens armados, porque v. revm. ha de saber que a policia atacou-me e quiz matar-me no logar chamado Maceté, onde houve mortes de um e de outro lado.

Notempodamonarchia deixei-meprender, porque reconhecia ogoverno; hoje não, porque nāo reconheço a Republica".

"Senhor, repliquei eu, se é catholico, deve considerar que a egreja condemna as revoltas, e, aceitando todas as formas de governo, ensina que os poderes constituidos regem os povos, em nome de Deus.

É assim em toda a parte: a França, que é uma das principaes nações da Europa, foi monarchia por muitos seculos, mas ha mais 
de 20 annosé Republica; e todoopovo, sem excepção dos monarchistas de lá, obedece ás autoridades $\mathrm{e}$ ás leis do governo.

Nós mesmos aqui no Brazil, a principiar dos bispos até o ultimo catholico, reconhecemos o governo actual; sómente vós nāo vos quereis sujeitar?

É mau pensar esse, é uma doutrina errada a vossa".

Interrompeu-me um dos da turba, gritando com arrogancia: "V. revm. é que tem uma doutrina falsa, e não o nosso Conselheiro". D'esta vez ainda o velho impoz silencio, e por unica resposta me disse:

"Eu não desarmo a minha gente, mas tambem não estorvo a santa missão". Não insisti no assumpto, e acompanhados da multidão, sahimos todos, indo escolher o logar para a latada e providenciar para que nodia seguinte principiassem os exercicios.

Feito isso, e quando me retirava, os fanaticos levantaram estrondosos vivas á Santissima Trindade, ao Bom Jesus, ao Divino Espirito Santo e ao Antonio Conselheiro.

Missionando em varias freguezias visinhas, eu havia já colhido informaçōes sobreAntonio Conselheiro e seusprincipaes sectarios; mas, estandoentre elles, quizantes de dar principio á minha pregação, averiguar o que realmente elles eram e o que faziam.

Do que vi e ouvi apurei o que passo a registrar, para que se aprecie melhor o occorrido.

Antonio Conselheiro, cujo nome de familia é Antonio Vicente Mendes Maciel, cearense, de cór branca tostada ao sol, magro, alto de estatura, tem cerca de 65 annos e pouco vigor physico, parecendo soffrer alguma affecção organica, por frequentes e violentos accessos de tosse a que é sujeito.

Com uma certa reputação de austeridade de costumes, envolvem-no tambem, e concorrem para alimentar a curiosidade de que é alvo e o prestigio que exerce, umas vagas, mas insistentes supposiçöes da expiação rigorosa de um crime, commettido, aliás, em circumstancia attenuantes.

Ninguem pode falar-lhe a sós, porque seus pretorianos não deixam, ou receiando pela vida do chefe, ou para nāo lhes escapar nenhum de seus movimentos e resoluçôes.

Antonio Conselheiro, inculcando zelo religioso, disciplina e orthodoxia catholica, não tem nada disso; pois contesta o ensino, transgride as leis e desconhece as autoridadeseclesiasticas, sempreque de algum modo lhe contrariam as idéias, ou os caprichos; e arrastando por esse caminho os seus infelizes sequazes, consente ainda que elles the prestem homenagens que importam um culto, e propalem em seu nome doutrinas subversivas da ordem, da moral e da fé.

Os alliciadores da seita se occupam em persuadir o povo de que todo aquelle que quizer se salvar precisa vir para os Canudos, porque nos outros logares tudo está contaminadoe perdidopela Republica: alli, porem, nem é preciso trabalhar; é a terra da promissão, onde corre um rio de leite, e são de cuscuz de milho os barrancos.

Quem tiver bens, disponha delles e entregue o producto da venda ao bom Consetheiro, nāo reservando para si mais do que um vintem em cada cem mil reis. Se possuir imagens, traga-as para osantuariocommum.

O que seguir isto á risca, terá direito a vestuario e ração; e contam-se em taes condições para mais de 800 homens e 200 mulheres no sequito do conhecido fanatico.

As mulheres se occupam em preparar a comida, coser e enfeitar os gorros de que usam os homens; e á noite vão cantar Bemditos na latada, accendendo fogueiras quando é tempo de frio.

Os homens estão sempre armados, e dia e noite, montam guarda a Antonio Conselheiro; parecem idolatral-o e cada vez que elle transpōe o limiar da casa em que mora é logo recebido com ruidosas acclamações e vivas á Santissima Trindade, ao Bom Jesus e ao Divino Espirito Santo.

Entre essa turba desorientada, ha varios criminosos, segundo me affirmaram, citando-se até os nomes, alguns dos quaes eu retive, como o de João Abbade, que é alli chamado o chefe do povo, natural do Tucano, e réo de dous homicidios, e o de José Venancio, a quem attribuem dezoito mortes.

O santo homem fecha os olhos a estas travessuras eacolhe os innocentes, para que não os venha a perder a Republica!

Quanto a deveres e praticas religiosas, Antonio Conselheiro nāo se arroga nenhuma funcção sacerdotal, mas tambem não dá jamais o exemplo de aproximar-se dos sacramentos, fazendo crêr com isto que não carece delles, nem do ministerio dos padres; e as ceremonias do culto a que preside, eque se repetem mais a miude entre os seus, são mescladas de signaes de superstição e idolatria, como é, por exemplo, o chamado Beija das imagens, a que procedem com profundas prostraçōes e culto egual a todas, 


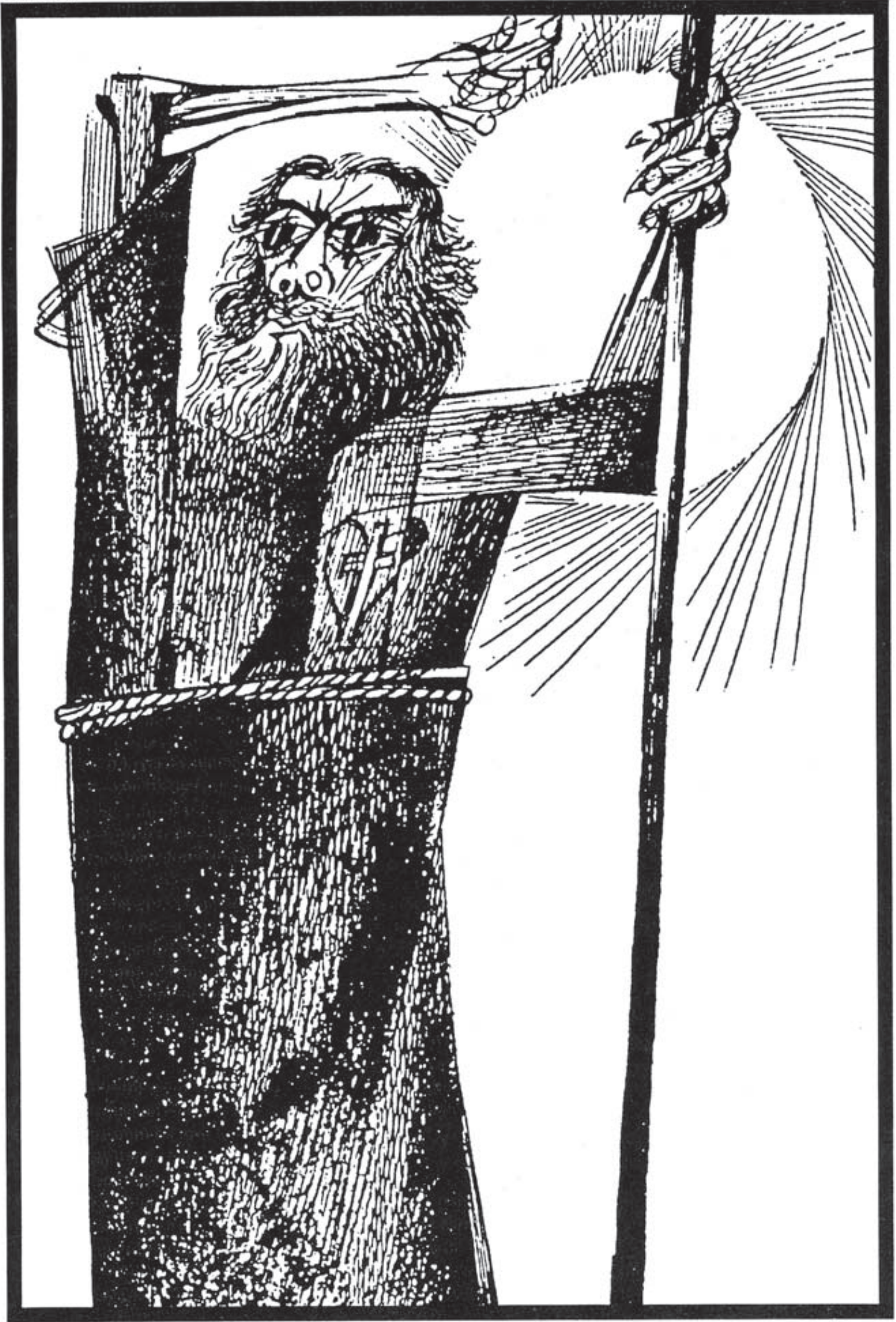


sem distincção entre as do Divino Crucificado, e da Santissima Virgem e quaesquer outras.

Antonio Conselheiro costuma reunir em certos dias o seu povo, para dar-lhe conselhos, que se resentem sempre do seu fanatismo em assumpto de religião e da sua formal opposição ao actual regimen politico; mas, ou para mostrar deferencia com o missionario, ou por ter meios de dar instrucçōes secretas, absteve-se de falar em publico, emquanto eu lá estive.

Abri a missāo a 14 de maio, e ja nesse dia concorreram não menos de quatro mil pessoas: dos homens, todos os que podiam manejar uma arma lá estavam, carregando bacamartes, garruchas, espingardas, pistolas e facōes; de cartucheira á cinta e gorro á cabeça, na attitude de quem vae á guerra. $\mathrm{O}$ Conselheiro tambem veio, trazendo o bordão: collocava-se ao lado do altar, e ouvia attento e impassivel; mas, como quem fiscalisa, e deixando escapar alguma vez gestos de desapprovação, que os maioraes da grei confirmavam com incisivos protestos. Succedeu istode um modomais notavel, certa occasião em que explicava o que era e como devia fazer-se o jejum, ponderando que elle tinha por fim a mortificação do corpo e o refreiamento das paixóes pela sobriedade e temperança, mas não o aniquilamento das forças por uma longa e rigorosa privação de alimentos, e que, por isso, a egreja para facilitar dispensava em muitos diasde jejum a abstinencia, enunca prohibiu o uso dos liquidos em moderada quantidade. Ouvindoquese podiajejuar muitas vezes comendo carne ao jantar, e tomando pela manhan uma chavena de café: o Conselheiro estendeu o labio inferior e sacudiu negativamente a cabeça, e os seus principaes asseclas romperam logo em apartes, exclamandocomemphase um dentre elles: "Ora, isto não é jejum, é comer a fartar".

Fóra essas ligeiras interrupçöes, a missão correu em paz até o quarto dia, em que eu preguei sobre o dever da obediencia á autoridade, e fiz ver que, sendo a Republica governo constituido no Brazil, todos os cidadāos, inclusive os que tivessem convicções contrarias, deviam reconhecel-o e respeital-o. Observ que neste sentido ja se pronunciara o Summo Pontifice, recommendando a concordia dos catholicos brazileiros com o poder civil; e conclui, declarando que se persistissem em desobedecer e hostilisar um governo que o povo brazileiro quasi na sua totalidade acceitara, não fizessem da religião pretexto ou capa de seus odios e caprichos, porque a egreja catholica não é nem será nunca solidaria com instrumentos de paixões e interesses particulares ou com perturbadores da ordem publica.

Estas minhas palavras irritaram o animo de muitos, e desde logo começaram a fazer propaganda contra a missão e os missionarios, arredando o povo de vir assistir á pregação de um padre maçon, protestante e republicano, e dirigindo-me, quando passavam e até ao pé do pulpito, ameaças de castigoe até de morte. Espalharam que eu era emissario do governo e que, de intelligencia com este, ia abrir caminho á tropa que viria de surpresa prender o Conselheiro e exterminar a todos elles. E, passando de palavras a factos, occuparam com gente armada todas as estradas dopovoado, pondo-o em estado de sitio, de modo a não poder ninguem entrar nem sahir sem ser antes reconhecido, como o fizeram ao proprio vigario da freguezia, detendo-o a bocca da estrada, quando ás 7 horas da noite, tendo se ausentado por justo motivo, regressava para os Canudos.

Roguei a Deus que amparasse a minha fraqueza, e, sem me afastar da calma e da moderação com que deve falar um missionario catholico, em um dos dias seguintes occupei-me dohomicidio, e, depois de considerar a malicia enorme e a irreparabilidade deste crime, entrei a mostrar que não eram homicidas só os que serviam-se do ferro ou do veneno para de emboscada ou de frente arrancar a vida aos seus semelhantes; que tambem o eram, até certoponto, aquelles que arrastavam outros a acompanhal-os em seus erros e desatinos, deixando-os depois morrer, dizimados pelas molestias, á mingua de recursos e até do pão, como acontecia alli mesmo; e, então, perguntei-lhes quem eram os responsaveis pela morte e pelo fim miseravel de velhos, mulheres e creanças que diariamente pereciamnaquelle povoadoem extrema penuria e abandono. Sahiu dentre a multidão uma voz lamuriosa dizendo assim: "É o Bom Jesus que os manda para o céo".

Exasperava-os a franqueza e a energia, com que o missionario lhes censurava os máus feitos, e não perdiam occasião de rugir contra elle, mas não se animavam a pôrlhe mãos violentas, porque havia mais de seis mil pessoas assistindo a missão, e a mór parte era gente de fóra que só a isto viera $\mathrm{e}$ reagiria certamente se elles me tocassem. 
Limitaram-se a injurias, acenos e ditos ameaçadores, até o dia 20 de maio, setimo da missão, em que já não se contiveram nessasmanifestaçōesisoladase organisaram um protesto geral e estrepitoso do grupo arregimentado. Desde as $\mathbf{1 1}$ horas da manhan,JoãoAbbade, chamado o chefe do povo, foi visto a percorrer a praça apitando impaciente, como a chamar a soldadesca a postos contra alguma aggressão inimiga, $\mathrm{e}$ a gente foi se reunindo, até que ao meio dia estava a Praça coalhada de homens armados, mulheres e meninos que, a queimar foguetes, e com uma algazarra infernal, dirigiam-se para a capella, erguendo vivas ao Bom Jesus, ao Divino Espirito Santo e a Antonio Conselheiro, e de lá vieram até nossa casa, dando fóras aos republicanos, maçons e protestantes, e gritando que não precisavam de padres para se salvar, porque tinham o seu Conselheiro.

Nessa desatinada passeiata, andaram acima e abaixo pela espaço de duas horas, dispersando-se afinal, sem irem além. 'A tarde, verberando a cegueira e insensatez dos que, assim haviam procedido, mostrei que tinha sidoaquilloum desacato sacrilego á religião e ao sagrado caracter sacerdotal, e que, portanto, punha termo á santa missão, e, como outr'ora os apostolos ás portas das cidades que os repelliam, eu sacudia alli mesmo o pó das sandalias, e retirava-me, annunciando-lhes que se a temponão abrissem os olhosáluz da verdade, sentiriam um dia o peso esmagador da Justiça Divina, a qual não escapam os que insultam os enviados do Senhor e despresam os meios de salvação. E os deixei, não voltando mais á latada, nem me prestando a exercer o meu ministerio em logar ou acto publico.

A suspensão repentina da santa missão produziu nos circumstantes o effeito de um raio, deixando-os attonitos e impressionados; os que ainda não se haviam alistado na companhia do Bom Jesus, que não recebiam do Conselheiro a comida e a roupa, e não dependiam delle portanto, deram-me plena razão, e, reprovando formalmente os desvarios de tal gente, começaram a sahir do povoado, já queixosos e completamente desilludidos das virtudes do Antonio Conselheiro.

Os outros, conhecendo-se em grande minoria, e avaliando que essa retirada em massa redundaria em notorio descredito delles, enviavam-me ás pressas uma commissão, em que entraram os mais exaltados, e que veiu pedir-me em nome do
Antonio Conselheiro a continuação da missão, allegando que não deviam soffrer os innocentes pelos culpados, e que assim ficaria o povo privado do Sacramento do Chrisma e de outros beneficios espirituaes que só no fim da missāo se lucravam. Descobrindo-lhes ao mesmo tempo a manha e a fraqueza, resisti aos pedidos, e deixei que o meu acto, mais feliz do que as minhas palavras, acabasse de operar a dispersão daquellas multidōes, presa imminente do fanatismo de um insensato, servido por imbecis ou explorado por perversos.

Haviam-se feito já, quando encerrei de chofre os trabalhos da missão, 55 casamentos de amancebados, 102 baptisados, e mais de 400 confissões.

No dia em que deviamos partir, fui pela manhan chamado para uma confissão de enfermo e acudi sem hesitação, seguindo uns homens armados que tinham vindo chamar-me a esse fim. Chegado á casa, interroguei odoente se queria confessar-se, e, respondendo que sim, pedi aos taes homens armados que sahissem para nāo ouvir a confissão. Elles não se moveram, e um perfilou-se e bradou "custe o que custar, não sahimos."

Observei, então, ao doente que nem eu podia ouvir a confissão, nem elle estava obrigado a fazel-a em taes circumstancias; e immediatamente retirei-me, protestando em vozalta, da porta da casa e na rua, contra aquella affrontosa violaçāo das leis da religiāo e da caridade.

Redobrou então a furia daquelles desvairados, e, vomitando insultos, imprecações e juras de vingança, tomaram a entrada da casa em que eu me hospedara e onde já me achava. A minha missão terminara: a seita havia levadoomaior golpe que eupodia descarregar-lhe, e conservar-me por mais tempo no meio daquella gente ou sahir-lhes ainda ao encontro, seria rematada imprudencia sem a minima utilidade. Os companheiros de viagem esperavam-nos com os animaes arreiados nos fundos da casa: dando costas aos miseros provocadores, de lá mesmo seguimos, e, galgando a estrada, aoolhar pela ultima vez opovoado, condoido da sua triste situação, como o Divino Mestre diante de Jerusalém, eu senti um aperto n'alma e pareceo-me poder tambem dizer-lhe:

"Desconheceste os emissarios da verdade e da paz, repelliste a visita da salvação: mas ahi vêm tempos em que forças 
irresistiveis te sitiarão, braço poderoso te derrubará, e arrazando as tuas trincheiras, desarmando os teos esbirros, dissolverá a seita impostora e maligna que te reduzio a seo jugo, odioso e aviltante".

Hoje, longe dessa infeliz localidade, e podendo informar sem resentimento e com toda a exactidão e justiça, eu recapitularei o exposto, dizendo o seguinte:

A missão de que fui encarregado, além da vantagem de apprehender e denunciar a impostura e perversidade da seita fanatica no proprio centro de suas operações, teve ainda um benefico effeito, que foi o de arrancar-lhe innumeras prezas, desenganando a uns das virtudes suppostas e premunindo outros contra as doutrinas e praticas abusivas e reprovadas de Antonio Conselheiro e de seus fanaticos discipulos. Descreram delle e felizmente já abandonaram multidōes consideraveis de povo que, regressando a suas terras, maldiz da hora em que os seguiu, e vai resgatar o seo erro pela obediencia ás legitimas autoridades e pelo trabalho.

Onde não chegarem as vozes dos que colheram tão amarga experiencia, faça-se ouvir a palavra autorisada dos pastores das almas, denunciando o caracter abominavel e a influencia malefica da seita, e ella de certo não logrará fazer novos proselytos.

Entretanto, comprazendo-me em consignar que só si conservam actualmente ao lado do Conselheiro aquelles que já estavam encorporados na legiâo por elles intitulada Companhia do Bom Jesus, no interesse da ordem publica e pelo respeito devido á lei, garanto a inteira veracidade do que informo e accrescento:

Aseita politico-religiosa, estabelecida e intrincheirada nos Canudos, não é só um foco de superstição e fanatismo e um pequeno schisma na egreja bahiana;é, principalmente, um nucleo, na apparencia despresivel, mas um tantoperigosoe funesto de ousada resistencia e hostilidade ao governo constituido no paiz.

Encarados o arrojo das pretenções e a soberania dos factos, pode-se dizer que é aquillo um estado no Estado: alli não são acceitas as leis, não são reconhecidas as autoridades, não é admittido á circulaçāo o proprio dinheiro da Republica.

Antonio Conselheiro conta a seu serviço mais de mil companheiros decididos: entre estes os homens, em numero talvez de oitocentos, sempre armados, e as mulheres e creanças dispostas de modo a formarem uma reserva que elle mobilisa e pöe em pé de guerra, quando julga preciso.

Quem foi alistado na Companhia difficilmente poderá libertar-se e vem a soffrer violencias, se fizer qualquer reclamação, como succedeu durante a minha estada a um pobre coitado que, por exigir a restituição das imagens que havia trazido, foi posto em prisão.

A milicia fanatica só dá entrada no povoado a quem bem lhe apraz; aos amigos do governo ou republicanos conhecidos ou suspeitos, ella faz logo retroceder ou tolera que entrem, mas trazendo-os em vista e prompta a expulsal-os; quanto aos indifferentes e que não se decidem a entrar na seita, esses podem viver alli, e têm liberdade para se occupar de seus interesses, mas correndo grandes riscos, e entre elles o de serem algum dia inesperadamente saqueadosos seus bensem proveito daSanta Companhia: sorte esta pouco invejavel, que ainda recentemente, coube a um certo negociante que lá se estabelecera, vindo da cidade do Bomfim.

Naquella infelizlocalidade, portanto, não tem imperio a lei, $\mathrm{e}$ as liberdades publicas estăo grosseiramente coarctadas.

$\mathrm{O}$ desaggravo da religião, o bem social e a dignidade do poder civil pedem uma providencia que restabeleça no povoadodos Canudos o prestigio da lei, as garantias do culto catholico e os nossos fóros de povo civilisado. Aquella situação deploravel de fanatismo e de anarchia deve cessar para honra do povo brazileiro para o qual é triste e humilhante que, ainda na mais inculta nesga da terra patria, o sentimento religioso desça a taes aberrações e o partidarismo politico desvaire em tão estulta e baixa reaç̧ão.

Releve-me v. ex. revma. a rudeza das considerações que expendi $\mathrm{e}$ a prolixidade desta exposiçăo, cujo intuito é mostrar o quanto esforçou-se o humilde missionario por desempenhar a tarefa que lhe foi confiada, e inteirar a v. ex. revma, do quanto occorreu por essa occasiáo e da attitude rebelde e bellicosa que Antonio Conselheiro e os seus sequazes assumiram e mantêm contra a egreja e oEstado; afim de que, dando ás informaçōes prestadas o valor que merecerem, delibere v. ex. revma. sobre o caso, comoem seualto criterioe reconhecidozelo julgar conveniente.

Deus guarde a v. ex. revma.

Exmo. e revm. sr. conego Clarindo de 


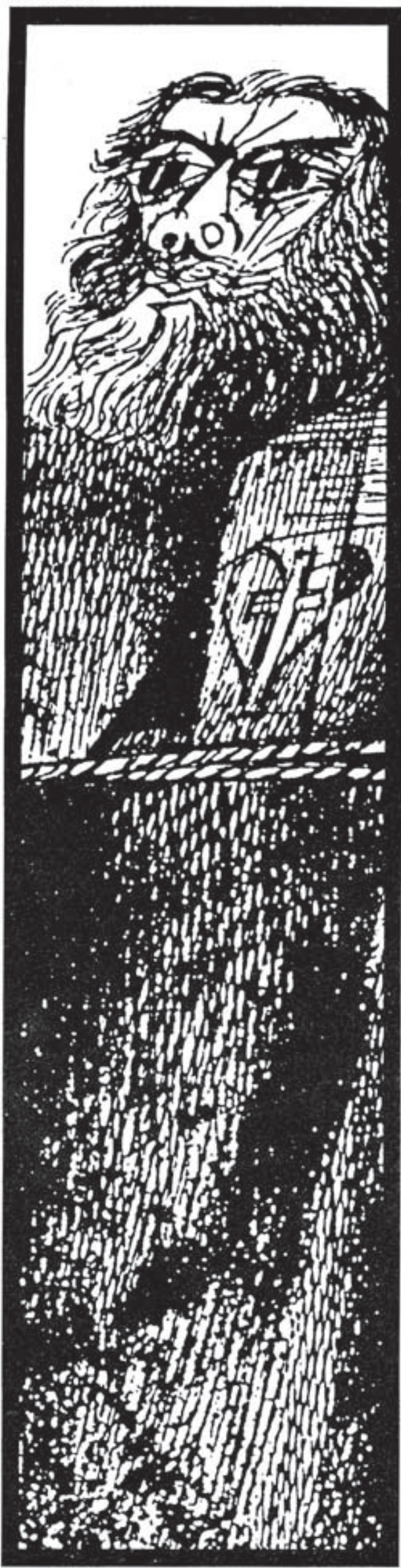

Souza Aranha, digno governador do arcebispado da Bahia. Frei João Evangelista de Monte Marciano, missionario apostolico capuchinho."

\section{BREVE CRONOLOGIA DA VIDA DE ANTÔNIO VICENTE MENDES MACIEL}

1830 - Nascimento a 13 de março, na viladoce Santo Antôniode Quixeramobim, Ceará Grande. Batismona Matrizlocal a 22 de maio. Registo de nascimento feito pela genitora, Maria Joaquina de Jesus.

1834 - Casamento, em articulo mortis, de Maria Joaquina com Vicente Mendes Maciel, tornando, assim, Antônio Vicente legitimado por conseqüente matrimônio.

1836 - Vicente Mendes Maciel, viúvo, contrai segundas núpcias com Francisca Maria Maciel. Homem feito, Antônio Conselheiro fazia queixas do tratamento que lhe fora dado pela madrastra.

1855 - Falecimento de Vicente Mendes Maciel. Seu filho assume a administração da casa comercial do genitor.

1856 - Falecimento da madrastra de Antônio Vicente.

1857-Antônio Vicente Mendes Maciel contrai matrimônio com sua parente, Brasilina Laurentina de Lima. Antônio Vicente deixa o comércio e inicia uma fase de andanças pelo sertão cearense, como professor primário, caixeiro, amansador de cavalos, rábula. Separa-se da mulher quando verifica a infidelidade da companheira.

1871 - Tem uns pequenos bens penhorados em conseqüência de dívida nãopaga. Está em Várzea da Pedra, no município de Quixeramobim.

1873-Aparece no Assaré(Ceará) como beato e conhece os irmãos Assunção, Antônio e Honório, depois chamados Vilanovas, de grande presença no povoado do Belo Monte.

1874 - Surge no centro das Províncias da Bahia e de Sergipe, onde inicia suas pregaçōes, desde logo ouvido e seguido por centenas de sertanejos. É conhecido como Santo Antônio dos Mares. Um semanário 
sergipano, $O$ Rabudo, editado na cidade de Estância, publica longa notícia a respeitoda estranha figura.

1876 - Já conhecido por Antônio Conselheiro, é preso na vila de Itapicuru e enviadopara a capital baiana. Suspeitava-se que ele houvesse cometido um crime em sua terra natal. Mandado para o Ceará é posto em liberdade pelo juiz de Quixeramobim, porque nada constava a respeito de delitos cometidos por Santo Antônio Aparecido, como também era conhecido.

1877 - Reaparece nos sertōes baianos com o prestígio muito maior. Inicia a construção ou reconstrução de capelas, muros de cemitérios, pequenos tanques d'água. É um benemérito dos sertổes.

1882 - O arcebispo de São Salvador da Bahia, D. Luís José dos Santos, envia circular ao clero do centro, proibindo que os vigários mantivessem entendimentos com o Bom Jesus Conselheiro, impedindo suas pregaçōes. Muitos vigários do interior não cumpriram a ordem do arcebispado.

1885 - O Conselheiro conclui as obras da capela de Senhor do Bonfim, em Chorrochó, uma das suas melhores obras, ainda intacta.

1892-Dá-se a bênçãoda capela do Bom Jesus, no arraial do Bom Jesus, hoje cidade deCrisópolis. Acerimônia foi realizadapelo vigário do Itapicuru, cônego Agripino Borges.Os jornais dão as primeiras notícias das pregaçóes anti-republicanas do Conselheiro.

1893 - Na vila do Soure, no nordeste baiano, seguidores do Conselheiro despedaçam as tábuas municipais onde figuravam os impostos estabelecidos pelas autoridades locais. Oato de rebeldia foi também praticado em outras localidades.

Em Masseté, município de Tucano, os conselheiristas enfrentam e vencem um destacamento da polícia baiana. Primeiro encontro armado do grupo conselheirista na noite de 26 de maio de 1893.

O governador Rodrigues Lima solicita ao marechal Floriano Peixoto a ajuda do governo federal para combater os rebelados.

Pedido prontamente atendido. Oitenta homens da guarniçãode linha seguiram para Serrinha, de onde deveriam rumar em per- seguição ao Conselheiro, já acompanhado de milhares de pessoas. Numa reunião em palácio, julgou-se mais prudente o recolhimento dos militares a Salvador, o que foi feito a 9 de junho.

Nos primeiros dias de junho, Antônio Conselheiro e seus acompanhantes alcançaram o povoado de Canudos que tomou a denominação de Belo Monte. Começava uma nova era na vida sertaneja e nacional. A capela de Santo Antônio, edificada por gente do Conselheiro e dirigida pelo beato Paulo José da Rosa, estava concluída e teria sido benzida no mês de agosto, com grandes festas.

1895 - A pedido do governador Rodrigues Lima, o arcebispo D. Jerônimo Tomé envia uma missão de frades capuchinhos ao Belo Monte para tentar, por meios suasórios a dissolução do povoado. O chefe da missāo, frei João Evangelista de Monte Marciano, contou em minucioso relatório o malogro de sua tarefa cristã, no mês de maio.

Em dezembro, seguido de grande número de adeptos, Antônio Conselheiropassa alguns dias na vila de Bom Conselho (Bahia), onde foi arrecadar recursos para as obras da nova igreja, que estava sendo levantada no Belo Monte, dedicada ao Bom Jesus.

1896 - Antônio Conselheiro, por intermédio de Joaquim Macambira, contrata a aquisiçāode madeira para a capela em construçāo, com comerciantes juazeirenses que retardaram a entrega de parte da encomenda, previamente paga. Espalhou-se em Juazeiro que os jagunços iriam buscar o material. Temeu-se a invasão da cidade. $\mathrm{O}$ juiz de direito dr. Arlindo Leoni transmitiu ao governador Luís Viana a notícia da ameaça. Para garantia do povo de Juazeiro seguiu uma tropa de linha, comandada pelo tenente Pires Ferreira. O oficial resolveu marchar contra Canudos e foi surpreendido, no povoado de Uauá, a 21 de novembro, pela jagunçada, que ele conseguiu pôr em retirada, mas ficou sem recursos para continuar no local. Retirou-se. Estava iniciada a guerra de Canudos.

Organizada a segunda expedição contra Canudos, sobocomandodomajor Febrônio de Brito. Surgem desinteligências entre o governador do estado, Luís Viana, e o comandante do Distrito Militar, generalSólon Ribeiro, que é afastado da chefia. 
1897 - A expedição Febrônio de Brito atravessa a serra do Cambaio, aproximando-se do arraial conselheirista. No lugar conhecidopor Tabolheirinhos de Canudos, depois Lagoa do Sangue, a tropa sofreu violento ataque dos jagunços e precisou recuar. Segundo insucesso do governo federal.

A opiniāo pública nacional fica alarmada. Consta que Canudos é um reduto monarquista ligado aos partidários da restauração monárquica em São Paulo e Rio. Encontra-se num republicano enérgico $\mathrm{e}$ destemido a espada vingadora. $\mathrm{O}$ coronel Antônio Moreira Cesarénomeadocomandante da Terceira Expedição, formada por mais de 1.200 homens, de todas as armas. A espetacular expediçăo foi desbaratada em março, morrendo seu famoso comandante. No Rio e em São Paulo grupos jacobinos reagiram violentamente atacando jornais e partidários da restauração.

Organiza-se a Quarta Expedição chefiada por um general da brigada, Artur Oscar de Andrade Guimarães, fervoroso republicano, que tem sob seu comando dois generais e vários coronéis. A expedição é dividida em duas colunas, partindo uma de Monte Santo e a outra de Aracaju na direção do Belo Monte, que resistiu durante algunsmeses, causandograndesperdas aos militares. Os ataques iniciados em junho somente em outubro dariam a vitória às armas republicanas. O Conselheiro morreu a 22 de setembro, e o povoado foi dominado a 5 de outubro. O cadáver de Antônio Conselheiro, sepultado na casa em que morrera, foi encontrado a 6 do referido mês. Sua cabeça veio para Salvador e foi estudada por um mestre da medicina legal, Nina Rodrigues.

Conclusão: cérebro normal.

No fim da guerra, uma chacina. Degolamentos em grande número. A opiniâo nacional que aprovara a luta com os supostos monarquistas condenou a mortandade dos sertanejos.

\section{SOBRE ANTÔNIO CONSELHEIRO Compilaçāo de José Calasans}

\section{OPINIŌES DE ESTUDIOSOS}

1893 - "Há cerca de 16 anos, em que vegetou pelos do Norte rezando nas igrejas e fazendo prédicas, que são assistidas pelas populaçōes das localidades em que se acha, onde sempre procura prestar algum serviço nas edificaçōes ou reedificaçốes de templos e cemitérios" (Durval Vieira de Aguiar).

1897 - "Alguma coisa mais do que a simples locura de um homem era necessária para este resultado e essa alguma coisa é a psicologia do meio em que a loucura do Antônio Conselheiro achou combustível para atear o incêndio de uma verdadeira epidemia vesânica" (Nina Rodrigues).

1897 - "O chefe Antônio Conselheiro, de cuja capacidade moral e intelectual faço lisonjeiro conceito..." (Siqueira Menezes).

1897 - "Ao encontrá-lo assim a última vez que o avistei em 1881 (sic), o seu prestígio era estupendo. Sentia que lidava com um profeta, com um dominador de multidóes. O seu olhar já não tinha a mesma abstração antiga. $\mathrm{O}$ hábito do comando tinha temperado o misticismo" (Genes Martins Fontes).

1902 - "Satisfez-se sempre com este papel de delegado dos céus. Não foi além" (Euclides da Cunha).

1954 - "O sertanejo não podia compreender os motivos por que era guerreado o Conselheiro. Durante anos vivera sob sua direção e só conhecera a prática do bem" (Abelardo Montenegro).

1968 - "Se considerarmos a época de suas realizações, as dificuldades sem conto para as tarefas empreendidas, justo é considerar os méritos de sua ação obreira, sem competidor na segunda metade do séoulo XIX, senãomesmoem todoevolverdazona sertaneja" (José Calasans).

1978 - "Percebe-se que ele (Conselheiro) realmente congregou os camponeses pobres, em certo momento deu expansão ao seu desencantamento e a sua revolta" (Rui Facó).

1978 - "Homem excepcional, sim, embora extremamente simples. Amante doseu povo, para cujo serviço sofreu muito e para cujo bem e progresso foi chefe e condutor" (Ataliba Nogueira).

1978-"Pode-se dizerque Antônio Conselheiro era um socialista utópico, que ten- 
tou organizar uma comunidade igualitária" (Edmundo Moniz).

1981 - "O homem era alto e tão magro que parecia sempre de perfil. Sua pele escu$\mathrm{ra}$, seus ossos proeminentes e seus olhos ardiam com fogo perpétuo. Calçava sandálias de pastor e a túnica de azulão que lhe caía sobre o corpo lembrava o hábito desses missionários que, de quando em quando, visitavam os povoados do sertão batizando multidões de crianças e casando amancebados" (Mario Vargas Llosa).

1990 - "Para as populações do litoral ele foi um louco, fanático religioso, um criminoso e bandido. Mas, para os sertanejos, ele foi um santo, o Bom Jesus ou o Santo Antônio, que sabia fazer milagres e curas, foi um Padrinho generoso e um penitente austero, modelode vida"(Alexandre H.Otten).

Quadra Popular:

"Quem quiser remédio santo

Lenitivo para tudo

Procure o Conselheiro

Que ele está lá em Canudos"

\section{Primeira fase - formação (1830-1873)}

Texto da certidão de batismo de Antônio Conselheiro:

"Aos vinte e dois de maio de mil oitocentos e trinta batizei e pus os Santos óleos nesta Matriz de Quixeramobim ao párvulo Antônio pardo nascido aos treze de março do mesmo ano supra, filho natural de Maria Joaquina: foram padrinhos, Gonçalo Nunes Leitão, e Maria Francisca de Paula.

Doque, para constar, fiz este termo, em que me assinei. O Vigário, Domingos Álvaro Vieira" (Ismael Pordeus - historiador cearense).

Texto da certidão in articulo mortis do casamento dos pais do Conselheiro:

"Aos trinta e hum de Agosto de mil oitocentos e trinta e quatro, pelas cinco horas da tarde em casa de morada do contrahente Vicente Mendes Maciel, omitidas as deligencias do costume por ser o casamento feito - in articulo mortis - assisti ao recebimento dos Contrahentes Vicente Mendes Maciel, filho natural de Maria
Manoela do Sacramento, já falecida, com Maria Joaquina de Jesus, filha natural de Feliciana MariaFrancisca, empresença das testemunhas José Antonio de Barros e José Raimundo Façanha, casados: os nubentes naturais, e moradores desta Freguezia de Santo Antonio de Quixeramobim e logo receberão as Bençãos Nupciais: do que para contar fiz este assento que assino. O Vigário Fructuoso Dias Ribeiro" (Ismael Pordeus).

Texto da certidão do $2^{g}$ casamento de Vicente Mendes Maciel, pai do Conselheiro:

"Aos doze dias de Fevereiro de mil oitocentos e trinta e seis, pelas oito horas da noite na Matriz desta Freguezia, ometidas as Denunciações do estilo, de licença minha o Reverendo Fructuoso Dias Ribeiro casou e deo as Benção Nupciais a Vicente Mendes Maciel, viúvo por falecimento de sua mulher Maria Joaquina de Jesus, comFrancisca Maria da Conceição, filha legítima de Innocencio Alves Freire e Joana Maria Conceição, já falecidos; forão testemunhas Franciscodas Chagas Pintoe José de Souza Nogueira, casado; todos moradores nesta Freguezia, do que para constar, do assento que me foi remettido, fiz o prezente termo que asigno. OVigário Pinto de Mendonça" (Ismael Pordeus).

Texto da certidão de casamento do Conselheiro:

"Aos sete dias do mês de janeiro de 1857, nesta matriz de Quixeramobim, pelas oito horas da noite, depois de preenchidas as formalidades de direito, assisti a receberemse em matrimônio e dei as bênçãos nupciais aos meus paroquianos Antônio Vicente Mendes Maciel e Brasilina Laurentina de Lima, naturais e moradores nesta freguezia de Quixeramobim, esta filha natural de Francisca Pereira de Lima e aquêle filho legítimo de Vicente Mendes Maciel e de Maria Joaquina do Nascimento, ambos já falecidos, sendo dispensados do impedimentodoterceiro grau atinente ao segundo, de consanguinidade lateral desigual; foram testemunhas José Raimundo Façanha e Pedro José de Matos; do que para constar mandei fazer este assento que assino. $\mathrm{O}$ Vigário interino José Jacinto Bezerra" (Gustavo Barroso, "À Margem da História do Ceará"). 
Oprofessor de latim deAntônio Conselheiro:

O Conselheiro estudou latim em Quixeramobim com o professor Manoel Antonio Ferreira Nobre, segundo informação de José Victor Ferreira Nobre, neto do referido mestre.

Beato e Conselheiro:

"Honório Vilanova, comerciante em Canudos, disse-nos que conhecera, por volta de 1873, no Ceará, o beato Antonio, que iria encontrar, depois, na Bahia, como conselheiro. Explicou que conselheiro era mais do que beato. Ao beato cabia a missão de tirar rezas, cantar ladainhas, pedir esmolas para obras da igreja. OConselheiro ia além, porque, melhor preparado sobre os temas religiosos, pregava, dava conselhos. Um conselheiro pode ter, debaixo de suas ordens, um ou vários beatos. Foi o caso de Antonio Conselheiro ao qual estavam subordinados alguns beatos, como o beato Paulo, José Beatinho, Antonio Beatinho, além de outros que não nos foi possível identificar" (José Calasans).

\section{Segunda fase - peregrinaçāo (1873-1893)}

\section{Primeira Notícia publicada em jornal so- bre Antônio Conselheiro:}

"A bons seis meses que por todo o centro desta e da Província da Bahia chegado; (diz elle,) da do Ceará infesta um aventureiro santarrão que se apellida por Antonio dos Mares: o que, avista dos apparentes e mentirosos milagres que disem ter elle feito tem dado lugar a que o povo o trate por S. Antonio dos Mares" (ORabudo - Estância, 22 de novembro de 1874).

\section{Apelidos:}

Santo Antonio dos Mares

Santo Antonio Aparecido

Antonio Conselheiro

Santo Conselheiro

Bom Jesus Conselheiro

Bom Jesus

"No Ceará declarou que tinha uma promessa a cumprir e pretendia construir 25 igrejas" (Honório Vilanova).
Edificou, realmente, em vários pontos da Bahia ede Sergipe, capelase levantou muros de cemitérios. Duas das referidas capelas mantêm a estrutura primitiva: a capela do Senhor do Bonfim em Chorrochó (1885) e a capela do Bom Jesus de Crisópolis(1892).

\section{PRÉDICAS}

Sobre a cruz:

"O homem deve carregar sua cruz debaixo de qualquer forma que se apresente, deve penetrar-se assim de júbilo, sabendo que em virtude dela vai ao céu".

Sobre a missa:

"Se bem soubera um cristão o que lucra em assistir e ouvir a missa todos os dias, deixaria os maiores negócios deste mundo para não faltar a tão grande bem espiritual".

Sobre a confissão:

"Não há cousa mais útil ao cristão nem indispensável para comungar dignamente do que descer à sua consciência e escrutar, com saudável severidade, seus tristes esconderijos".

Sobre a República:

"Éevidentequea república permanece sobre um princípio falso e dele não se pode tirar conseqüência legítima: sustentar o contrário seria absurdo, espantoso e singularíssimo; porque, ainda que ela trouxesse o bem para o país, por si é má, porque vai de encontro à vontade de Deus, com manifesta ofensa de sua divina lei. Como podem conciliar-se a lei divina e as humanas, tirando o direito de quem tem para dar a quem não tem? Quem não sabe que o digno príncipe, o senhor dom Pedro $3^{2}$, tem poder legitimamente constituído por Deus para governar o Brasil?"

Sobre o casamento civil:

"A religiāosantifica tudoe nãodestrói cousa alguma, exceto o pecado. Daqui se vê que o casamento civil ocasiona a nulidade do casamento, conforme manda a santa madre Igreja de Roma, contra a disposição mais clara do seu ensino". 
...”o casamento é puramente da competência da santa Igreja, que só seus ministros têmpoder para celebrá-lo; nãopode portanto o poder temporal de forma alguma intervir neste casamento, cujomatrimônio na lei da graça Nosso Senhor Jesus Cristo o elevou à dignidade de sacramento... é prudente $\mathrm{e}$ justo que os pais de família não obedeçam à lei do casamento civil, evitando a gravíssima ofensa em matéria religiosa que toca diretamente a consciência e a alma".

"Ele ali subia e pregava. Era assombroso, afirmam testemunhas existentes. Uma oratória bárbara e arrepiadora, feita de excertos truncados das Horas Marianas, desconexa, abstrusa agrava, às vezes, pela ousadia extrema das citaçōes latinas; transcorrendoem frases sacudidas: misto inextricável e confuso de conselhos dogmáticos, preceitos vulgares da moral cristã e de profecias esdrúxulas... Era truanesco e era pavoroso. Imagine-se um bufão arrebatado numa visão do Apocalipse..."(Euclides da Cunha).

\section{Pessoas que ouviram o Conselheiro pre- gando depōem:}

"Quando por ali passamos achava-se na povoação um célebre Conselheiro, sujeito baixo, moreno acaboclado, de barbas e cabelos pretos e crescidos, vestido de camisolão azul, morando sozinho em uma desmobiliada casa, onde se apinhavam as beatas e afluíam os presentes, com os quais se alimentava. Este sujeito é mais um fanático ignorante do que um anacoreta, e a sua ocupação consiste em pregar uma incompleta moral, ensinar rezas, fazer prédicas banais, rezar terços e ladainhas com opovo; servindo-se para isso das igrejas, onde, diante do viajante civilizado, se dá a um irrisório espetáculo, especialmente quando recita um latinório que nem os ouvidos entendem"(Durval Vieirade Aguiar-1888).

"Pálido e magro-de magreza esquelética, alto, com os cabelos compridíssimos, enfiado em uma túnica azul, a cuja cinta estava atado um cordão de frade franciscano, do qual pendia um crucifixo...

Na cabeleira via-se o pulular dos piolhos... Se a cabeça era assim, as mãos sujas, as unhas compridas e sórdidas; tudo completava a sua nojenta figura.

O que, porém, lhe dava o tom à fisionomia era o olhar. O olhar boiava naquela abstração vaga, naquela expressã̃o e cisma indefinível, que caracterizamos místicos os sonhadores, os alucinados. Fitava um ponto de espaço, olhando sem ver, absorvido em êxtases" (Genes Fontes - 1879).

"Seguiu a risca o mesmo ritual dos pregadores sacros. Persignou-se: e as suas primeiras palavras foram um latinório truncado, verdadeiras silabadas na língua de Horácio.

O tema do seu conselho versou sobre a família. Falou uma hora mais ou menos. Quandoterminou, ajoelhou-se diante deum altar e rezou-se a ladainha.

Saí ao terminar; e saí convicto de que o Conselheiro era um fanático" (Caldas Brito - 1892).

"AmissāodoConselheiro foi essencialmente espiritual... Dir-se-ia que o Conselheiro não praticou o culto da personalidade, que não quis ser endeusado. São coincidentes os testemunhos de que nunca pretendeu exercer funçōes sacerdotais. Todos são categóricos: dava conselhos, construía capelas, cemitérios, e isso era tudo" (Mario Vargas Llosa).

\section{A prisāo do Conselheiro}

"Esse misterioso, que dizem viera do Ceará e tem percorrido nosso centro, acaba de ser preso pelo delegado de polícia de Itapicuru e é aqui esperado nestes dias, pois foi uma escolta para conduzi-lo" (Diário da Bahia -27 de junho de 1876).

"No Pernambuco seguiu ontem para a Província do Ceará, a fim de ser ali presente ao senhor chefe de Polícia, o indivíduo Antônio Vicente Mendes Maciel, vulgo Antônio Conselheiro...

S. Exa. Revdma, o sr. vigário capitular, requisitou ao sr. Dr. Chefe de Polícia a prisāo deste hipócrita, por haver as mais fundadas suspeitas de ser ele um dos célebres foragidos do terrível morticínio que se deu no Ceará em novembro de 1872 ...

Antônio Conselheiro recusou obstinadamente responder ao interrogatório que lhe foi feito na secretaria de Polícia, sendo por isso enviado para o Ceará afim de ser ali processado" (Jornal da Bahia - 7 de julho de 1876). 
O magistrado de Quixeramobim, apurando que nada havia contra Antônio Vicente, colocou-o em liberdade e ele voltou para a Bahia, como havia anunciado a seus seguidores. .

\section{Terceira fase - Canudos (1893-1897)}

Em junho de 1893 o Conselheiro fixou-se em Canudos, povoado banhado pelo rio Vasa-Barris. O local passou a ser denominado Belo Monte. Cresceu em pouco tempo. Tornou-se a localidade de maior população da Bahia, depois da capital - cerca de 25.000 habitantes.

Canudos foi rebatizada pelo Conselheiro com o nome de Belo Monte.

Homens e mulheres remediados venderam seus pequenos bens, deixaram suas terras e foram viver e morrer no chäo sagrado do Belo Monte.

Em 1895, a pedido do governador do estado, o arcebispo D. Jerônimo Tomé enviou uma missão de frades capuchinhos para tentar dissolver por meios suasórios o arraial do Belo Monte. A missão foi entregue a frei Joẫo Evangelista de Monte Marciano e não teve sucesso. O relatório do frade é um documento importante para o conhecimento da vida dos canudenses.

A construção da igreja nova de Canudos provocou o início da guerra.

João Evangelista Pereira de Melo (coronel Janjāo - 1841-1910), comerciante de Juazeiro, intermediou osentendimentos para a aquisição do madeirame destinado à igreja nova de Canudos.

Com a demora na entrega da madeira, espalhou-se a notícia que os jagunços iriam buscar o material, invadindo a cidade. Foi enviada uma tropa, pelo governador da Bahia, comandada pelo tenente Pires Ferreira, que resolveu nāo aguardar em Juazeiro e marchou contra Canudos. Deuse mal. Atacado, defendeu-se, porém teve de recuar. Começava a guerra sangrenta, que durou quase um ano. Mais três expedições foram enviadas contra Canudos e somente a última, após insucessos parciais, ganhou a peleja.
A vitória na guerra:

"De que nos serviu ela? Ela não foi mais do que um pactovergonhoso, realizado à sombra do auri-verde pavilhāo e escudado pela efígie da República..."

"Em Canudos foram degolados quase todos os prisioneiros".

"Apósoentusiasmodos primeiros momentos da vitória começou-se a demolição de todas as edificaçöes existentes..."

“...tratou-se de pôr em prática o plano traçado pelo general-em-chefe: - Não deixar ficar em pé nem um só pau que indicasse ter havido ali uma choça sequer".

"Em primeiro lugar foram colocados barris de pólvora sob os alicerces das igrejas novas e velhas, sendo elas imediatamente destruídas" (Alvim Martins Horcardes Acadêmico de Medicina e diretor do Hospital de Variolosos de Canudos na $4^{\mathrm{a}}$ expedição militar).

Um terço do exército brasileiro foi mobilizado para aniquilar Canudos.

Canudos nāo se rendeu: resistiu até a morte do último combatente.

Primeira Expedição:

Comandante: Ten. Manuel da Silva Pires

Ferreira

Força: Aproximadamente 120 homens

Segunda Expedição:

Comandante: Major Febrônio de Brito

Força: Aproximadamente 625 homens, de diversas repartiçổes dos Estados de Alagoas, Sergipe e Bahia.

\section{Terceira Expedição:}

Comandante: Cel. Antonio Moreira César Força: Aproximadamente 1.300 homens mais o remanescente da segunda expedição.

Quarta Expediçāo:

Comandante-em-chefe: Gen. Artur Oscar de Andrade Guimarāes

Força: Mais de 10.000 militares 